\title{
Investigation of cytotoxicity and in-vitro antioxidant activity of Asparagus racemosus root extract
}

Md. Ismail Hossain, Farzana Anwar Sharmin, Sadika Akhter, Mohiuddin Ahmed Bhuiyan, *Mohammad Shahriar

Department of Pharmacy, University of Asia Pacific, Dhanmondi, Dhaka, Bangladesh

\begin{abstract}
This attempt is made to address the phytoconstituents, free radical scavenging activity and brine shrimp lethality bioassay of five different extracts of Asparagus racemosus roots. Preliminary phytochemical examination of the crude extracts of Asparagus racemosus root disclosed the existence of different sort of chemical groups such as flavonoids, tannin, saponin, alkaloids, carbohydrate. The root displayed significant DPPH free radical scavenging activity with highest IC 50 value showed by ethanol extract with a value of $78.15 \mu \mathrm{g} / \mathrm{ml}$ followed by methanol and petroleum ether having value of $106.44 \mu \mathrm{g} / \mathrm{ml}$ and $273.31 \mu \mathrm{g} / \mathrm{ml}$ respectively as opposed to that of the scavenging effects of ascorbic acid and BHT of $5.698 \mu \mathrm{g} / \mathrm{ml}$ and $8.816 \mu \mathrm{g} / \mathrm{ml}$ respectively. The highest reducing power was showed by ethanol extract followed by methanol and petroleum ether as opposed to that of the reducing potential of ascorbic acid and BHT. The fractions represented good cupric reducing capacity with increasing concentration taking ethanol extract in the top position. The ethanol extract yielded $108.78 \pm 2.77 \mathrm{mg} / \mathrm{gm}$ gallic acid equivalent phenolic content and methanol sub-fraction yielded $164.77 \pm 1.73 \mathrm{mg} / \mathrm{gm}$ quercetin equivalent flavonoid content that was highest among five extracts. Ethanol extract of Asparagus racemosus was found to possess the highest total antioxidant capacity (639.925 \pm 64.78$)$ $\mathrm{mg} / \mathrm{gm}$ followed by methanol $(616.92 \pm 53.88) \mathrm{mg} / \mathrm{gm}$ and petroleum ether $(469.17 \pm 52.95) \mathrm{mg} / \mathrm{gm}$ ascorbic acid equivalent respectively. In brine shrimp lethality bioassay, $\mathrm{LC}_{50}$ values for ethanol, methanol, petroleum ether, $\mathrm{n}$ hexane and chloroform were found to be $0.674 \mu \mathrm{g} / \mathrm{ml}, 0.719 \mu \mathrm{g} / \mathrm{ml}, 0.984 \mu \mathrm{g} / \mathrm{ml}, 2.157 \mu \mathrm{g} / \mathrm{ml}$ and $1.514 \mu \mathrm{g} / \mathrm{ml}$ respectively. N-hexane and chloroform extract showed least activity in all the measures. The results suggest that Asparagus racemosus is a valuable source of antioxidant and has significant cytotoxic activity hence could eliminate many diseases related to free radical.
\end{abstract}

Key Words: Radical scavenging, DPPH, phenolic, flavonoid, cupric, reducing power.

\section{INTRODUCTION}

For decades, the utilization of herbal plants has drawn avalanche of interest as they could accommodate therapeutic response and are promising candidate to be developed as pharmaceutical products. Presently, complication has arised in severity and extent in combating bacterial and fungal infections on behalf of the development of bacteria and fungi resistant to many current antibiotics (Aderogba et al., 2005; Rabaud et al., 1997). Free radicals have been accused of initiating many serious diseases (Malorni et al., 1998; Robert and

\footnotetext{
*Corresponding Author:

Mohammad Shahriar, Assistant Professor

Department of Pharmacy

University of Asia Pacific

House: 73, Road: 5A, Dhanmondi, Dhaka-1209, Bangladesh.

E-mail: shahriar@uap-bd.edu

Contact No.: +88 01199844259
}

Meunier, 1998; Pauli et al., 2005; Shah, 2005; Rios and Recio, 2005). These free radicals drive oxidative stress and transform the pathophysiological condition of the patient by acting on immune system. It has been known that phenolic and flavonoid compounds of the plant extracts are responsible for antioxidant and antibacterial effects (Da-Silva et al., 2006; Majhenic et al., 2007; Pereira et al., 2007). Asparagus racemosus (Liliaceae), locally known as 'Shatamuli', is a woody climber growing to $1-2 \mathrm{~m}$ in height. The Bangladeshi local name 'Shatamuli' refers to its finger-like and many clustered roots. The leaves are like pine-needles, small and uniform. The inflorescence has tiny white flowers, in small spikes (Potduang et al., 2008). The plant is common at low altitudes in shade and in tropical climates throughout Asia, Australia and Africa. In India, the plant is called Shatavari in Hindi. Recent research 
indicates Shatavari enhances immune function, increases corticosteroid production, and promotes cell regeneration (Rege et al., 1999). The root has long been used in Ayurveda as a tonic remedy to promote fertility and reducing menopausal symptoms (Pandey et al., 2005). It is also used for dry coughs and gastric ulcers (Mandal et al., 2000). It is mainly known for its phytoestrogenic properties. In Ayurveda, Asparagus racemosus has been used extensively as an adaptogen to increase the nonspecific resistance of organisms against a variety of stresses (Visavadiya et al., 2009; Wiboonpun et al., 2004). Besides use in the treatment of diarrhoea and dysentery, the plant also has antioxidant, immunestimulant, anti-dyspepsia and anti-tussive effects (Visavadiya et al., 2009; Wiboonpun et al., 2004; Kamat et al., 2000; Ojha et al., 2010; Gautam et al., 2009; Mandal et al., 2000).

Judging the therapeutic potential of the plant and different phytoconstituents in different solvents, we compared the efficiency of the ethanolic, methanolic, chloroform, n-hexane and petroleum ether extracts of Asparagus racemosus roots. Literature survey revealed that, no such comparative investigation has been carried out for the Asparagus racemosus root extracts. Comparisons of the phytochemical constituents as well as antioxidant activity of the different extracts were also carried out.

\section{MATERIALS AND METHODS}

\section{Chemicals}

1, 1 diphenyl-2-picrylhydrazyl (DPPH), butylated hydroxy anisole (BHA), were obtained from Sigma Aldrich. Other chemicals, sodium carbonate, sodium phosphate, potassium acetate, methanol, ethanol, petroleum ether, butylated hydroxyl toluene (BHT), gallic acid, neocaproin, potassium di-hydrogen phosphate, acetic acid (glacial), cupric chloride, concentrated $\mathrm{H}_{2} \mathrm{SO}_{4}(96 \%), \mathrm{H}_{2} \mathrm{O}_{2}(30 \%$, v/v) were obtained from (Merck KGaA, Darmstadt, Germany). Sodium nitroprusside, sulphanilamide, ascorbic acid, ferric chloride, n-hexane, naphthyl ethylenediamine dihydrochloride, folin - ciocalteu reagent were from Loba Chemie Pvt. Ltd, India. Trichloro acetic acid, sodium chloride crystal, sodium hydroxide pellets, chloroform, ammonium acetate were from Merck Specialities Private Limited, India. Potassium ferricyanide was from UNI-CHEM, China. Ammo- nium molybdate was from BDH Chemicals Ltd, England. Aluminium chloride was from UNI-CHEM, China. Quercetin was from Aldrich Chemistry, Switzerland.

\section{Collection and identification}

The root of Asparagus racemosus was collected during August, 2011 from Old Town, Dhaka. The root was identified and authenticated by taxonomist of the National Herbarium of Bangladesh, Mirpur, Dhaka (DACB, Accession No. 35906).

\section{Drying and extraction procedure}

After complete cleaning and rinsing with distilled water roots were sun dried for fifteen days and then dried in an oven at $40^{\circ} \mathrm{C}$ for 3 days. The dried roots were then grinded to coarse powder using high capacity grinding machine. The powdered plant material $(20 \mathrm{gm})$ was successively extracted in a Soxhlet extractor at elevated temperature using 200 $\mathrm{ml}$ of distilled petroleum ether $(40-60)^{\circ} \mathrm{C}$ which was followed by n-hexane, ethanol, chloroform and methanol. All extracts were filtered individually through filter paper and poured on petri dishes to evaporate the liquid solvents from the extract to get dry extracts. The dry crude extracts were weighed and stored in air-tight container with necessary markings for identification and kept in refrigerator $4^{\circ} \mathrm{C}$ for future investigation.

\section{Determination of Total Phenolic Content}

Total phenolic contents in the extracts were determined by the Folin-Ciocalteu reagent method described by Demiray et al., (2009). $1 \mathrm{ml}$ of the plant extracts/standard of different concentration solution was mixed with $5 \mathrm{ml}$ Folin-Ciocalteu reagent (previously diluted with water 1:10 v/v) and $4 \mathrm{ml}$ (7.5\% sodium carbonate) of sodium carbonate. The tubes were vortexed for few seconds and allowed to stand for $30 \mathrm{~min}$ at $20^{\circ} \mathrm{C}$ for color development. Absorbance of samples and standard were measured at $765 \mathrm{~nm}$ using spectrophotometer against blank. A typical blank solution contained the solvent used to dissolve the plant extract. The total content of phenolic compounds of plant extracts in gallic acid equivalent (GAE) was calculated using the following equation:

$C=(c \times V) / m$

where; $\mathrm{C}=$ total content of phenolic compounds, $\mathrm{mg} / \mathrm{gm}$ plant extract, in GAE, $\mathrm{c}=$ concentration of 
Table 1: Total phenol contents of the different extracts of Asparagus racemosus.

\begin{tabular}{ll}
\hline Extract & $\begin{array}{l}\text { Total Phenol Contents } \\
\text { (mg/gm, Gallic Acid Equivalent) }\end{array}$ \\
\hline Methanol & $92.97 \pm 3.50$ \\
Ethanol & $108.78 \pm 2.77$ \\
Petroleum ether & $55.47 \pm 1.83$ \\
n-hexane & $22.47 \pm 3.14$ \\
Chloroform & $79.74 \pm 4.77$
\end{tabular}

Values are the mean of duplicate experiments and represented as mean $\pm \mathrm{SD}$

gallic acid established from the calibration curve $(\mathrm{mg} / \mathrm{ml}), \mathrm{V}=$ volume of extract in $\mathrm{ml}, \mathrm{m}=$ weight of crude plant extract in gm.

\section{Determination of Total Flavonoids Content}

Aluminum chloride colorimetric method was used for flavonoids determination (Wang et al., 2000). 1 $\mathrm{ml}$ of the plant extracts/standard of different concentration solution was mixed with $3 \mathrm{ml}$ of methanol, $0.2 \mathrm{ml}$ of aluminum chloride, $0.2 \mathrm{ml}$ of 1 $\mathrm{M}$ potassium acetate and $5.6 \mathrm{ml}$ of distilled water. It remained at room temperature for $30 \mathrm{~min}$; the absorbance of the reaction mixture was measured at $415 \mathrm{~nm}$ with spectrophotometer against blank. Methanol served as blank. The total content of flavonoid compounds of plant methanol extracts in quercetin equivalent was calculated by the following equation:

$C=(c \times V) / m$

where; $\mathrm{C}=$ total content of flavonoid compounds, $\mathrm{mg} / \mathrm{gm}$ plant extract, in quercetin equivalent, $\mathrm{c}=$ concentration of quercetin established from the calibration curve in $\mathrm{mg} / \mathrm{ml}, \mathrm{V}=$ volume of extract in $\mathrm{ml}$ and $\mathrm{m}=$ weight of crude plant extract in $\mathrm{gm}$.

\section{Determination of Total Antioxidant Capacity}

The total antioxidant capacity was evaluated by the phosphomolybdenum method (Prieto et al., 1999). $0.3 \mathrm{ml}$ of extract and sub-fraction in ethanol, ascorbic acid used as standard $(5-200 \mu \mathrm{g} / \mathrm{ml})$ and blank (ethanol) were combined with $3 \mathrm{ml}$ of reagent mixture separately and incubated at $95^{\circ} \mathrm{C}$ for 90 minutes. After cooling to room temperature, the absorbance of each sample was measured at $695 \mathrm{~nm}$ against the blank. The antioxidant activity is expressed as the number of equivalents of ascorbic acid and was calculated by the following equation: $A=(c \times V) / m$
Table 2: Total flavonoid contents of the different extracts of Asparagus racemosus.

\begin{tabular}{ll}
\hline Extract & $\begin{array}{l}\text { Total Flavonoid Contents } \\
(\mathbf{m g} / \mathbf{g m}, \text { Quercetin Equivalent) }\end{array}$ \\
\hline Methanol & $164.77 \pm 1.73$ \\
Ethanol & $128.73 \pm 6.0$ \\
Petroleum ether & $104.18 \pm 3.0$ \\
n-hexane & $70.4 \pm 3.76$ \\
Chloroform & $56.32 \pm 3.95$ \\
\hline
\end{tabular}

Values are the mean of duplicate experiments and represented as mean \pm SD.

where, $\mathrm{A}=$ total content of antioxidant compounds, $\mathrm{mg} / \mathrm{gm}$ plant extract, in ascorbic acid equivalent $\mathrm{c}=$ concentration of ascorbic acid established from the calibration curve, $\mathrm{mg} / \mathrm{ml}, \mathrm{V}=$ volume of extract in $\mathrm{ml}$, $\mathrm{m}=$ weight of crude plant extract, $\mathrm{gm}$.

\section{DPPH Free Radical Scavenging Assay}

The free radical scavenging capacity of the extracts was determined using DPPH (Braca et al., 2001). Freshly prepared DPPH solution was taken in test tubes and extracts were added followed by serial dilutions ( $15.625 \mu \mathrm{g} / \mathrm{ml}$ to $250 \mu \mathrm{g} / \mathrm{ml})$ to every test tube so that the final volume was $5 \mathrm{ml}$ and after 30 min, the absorbance was read at $517 \mathrm{~nm}$ using a spectrophotometer. Ascorbic acid and butylated hydroxy toluene (BHT) was used as standard. Control sample was prepared containing the same volume without any extract and standard and the absorbance was read at $517 \mathrm{~nm}$ using a spectrophotometer. Methanol was served as blank.

\section{Reducing Power Capacity Assessment}

Assay of reducing power was carried out by potassium ferricyanide method (Yildirim et al., 2001). $1 \mathrm{ml}$ of extract and its sub-fractions (final concentration 5- $200 \mu \mathrm{g} / \mathrm{ml}$ ) were mixed with $2.5 \mathrm{ml}$ phosphate buffer $(0.2 \mathrm{M}, \mathrm{pH} 6.6)$ and $2.5 \mathrm{ml}$ potassium ferricyanide. The mixture was then incubated at $50^{\circ} \mathrm{C}$ for 20 minutes. To this mixture $2.5 \mathrm{ml}$ of trichloroacetic acid was added, which was then centrifuged at $3000 \mathrm{rpm}$ for 30 minutes. Finally, 2.5 $\mathrm{ml}$ of the supernatant solution was collected and mixed with $2.5 \mathrm{ml}$ of distilled water and $0.5 \mathrm{ml}$ ferric chloride and absorbance was measured at $700 \mathrm{~nm}$. Ascorbic acid and BHT were used as standard and phosphate buffer as blank solution. 
Table 3: Total antioxidant capacity of the different extracts of Asparagus racemosus.

\begin{tabular}{ll}
\hline Extract & $\begin{array}{l}\text { Total Antioxidant Capacity } \\
\text { (mg/gm, Ascorbic Acid Equivalent) }\end{array}$ \\
\hline Methanol & $616.92 \pm 53.88$ \\
Ethanol & $639.925 \pm 64.78$ \\
Petroleum ether & $469.17 \pm 52.95$ \\
n-hexane & $314.67 \pm 70.97$ \\
Chloroform & $367.175 \pm 23.73$
\end{tabular}

Values are the mean of duplicate experiments and represented as mean $\pm \mathrm{SD}$.

\section{Cupric Reducing Antioxidant Capacity (CUPRAC)} The assay was conducted as described previously (Apak et al., 2004). To $0.5 \mathrm{ml}$ of plant extract or standard of different concentrations solution, $1 \mathrm{ml}$ of copper (II) chloride solution (0.01 M prepared from $\left.\mathrm{CuCl}_{2} 2 \mathrm{H}_{2} \mathrm{O}\right), 1 \mathrm{ml}$ of ammonium acetate buffer at $\mathrm{pH} 7.0$ and $1 \mathrm{ml}$ of neocaproin solution $(0.0075 \mathrm{M})$ were mixed. The final volume of the mixture was adjusted to $4.1 \mathrm{ml}$ by adding $0.6 \mathrm{ml}$ of distilled water and the total mixture was incubated for 1 hour at room temperature. Then the absorbance of the solution was measured at $450 \mathrm{~nm}$ using a spectrophotometer against blank. Ascorbic acid, BHT and BHA were used as a standard.

\section{RESULTS}

\section{Total Phenolic Content}

Total phenolic content of the different extracts of Asparagus racemosus root was determined by using the Folin-Ciocalteu reagent and were expressed as gallic acid equivalent per gram of plant extract. The total phenolic contents of the test fractions were calculated using the standard curve of gallic acid (y $\left.=0.013 x+0.037 ; R^{2}=0.994\right)$. Ethanol extract of Asparagus racemosus was found to contain the highest amount of phenols. Phenol contents of the extracts were found to decrease in the following order: ethanol extract $>$ methanol extract $>$ chloroform extract $>$ petroleum ether extract $>$ n-hexane extract (Table 1).

\section{Total Flavonoid Content}

Aluminium chloride colorimetric method was used to determine the total flavonoid contents of the different extracts of Asparagus racemosus. Total flavonoid content was calculated using the standard curve of quercetin $\left(y=0.0148 x-0.0624 ; R^{2}=0.9944\right)$
Table 4: IC 50 values of different extracts of Asparagus racemosus in DPPH scavenging assay.

\begin{tabular}{ll}
\hline Extracts/standard & IC $_{\mathbf{5 0}} \boldsymbol{\mu \mathrm { g }} / \mathrm{ml}$ \\
\hline Methanol & 106.44 \\
Ethanol & 78.15 \\
Petroleum ether & 273.31 \\
n-hexane & 990.48 \\
Chloroform & 712.61 \\
Ascorbic acid & 5.698 \\
Butylated hydroxy toluene (BHT) & 8.816 \\
\hline
\end{tabular}

and was expressed as quercetin equivalent per gram of the plant extract. Methanol extract of Asparagus racemosus was found to contain the highest amount of flavonoid (Table 2). Flavonoid contents of the extracts were found to decrease in the following order: methanol extract $>$ ethanol extract $>$ petroleum ether extract $>$ chloroform extract $>$ n-hexane extract.

\section{Total Antioxidant Capacity}

Total antioxidant capacity of different extracts of Asparagus racemosus was evaluated by the phosphomolybdenum method and was expressed as ascorbic acid equivalent per gram of plant extract. Total antioxidant capacity of the test samples was calculated using the standard curve of ascorbic acid $\left(y=0.002 x+0.001 ; R^{2}=0.997\right)$. Ethanol extract of Asparagus racemosus was found to possess the highest total antioxidant capacity (Table 3). Total antioxidant capacity of the extracts was found to decrease in the following order: ethanol extract $>$ methanol extract $>$ petroleum ether extract $>$ chloroform extract $>$ n-hexane extract.

\section{DPPH Free Radical Scavenging Assay}

The free radical scavenging activity of different extracts of Asparagus racemosus root was studied by its ability to reduce the DPPH, a stable free radical and any molecule that can donate an electron or hydrogen to DPPH, can react with it and thereby bleach the DPPH absorption. DPPH is a purple colour dye having absorption maxima of $517 \mathrm{~nm}$ and upon reaction with a hydrogen donor the purple colour fades or disappears due to conversion of it to 2, 2-diphenyl-1-picryl hydrazine resulting in decrease in absorbance. Ethanol, methanol and petroleum ether extracts showed maximum activity of $65.35 \%, 62.76 \%$ and $52.53 \%$ respectively at $250 \mu \mathrm{g}$ 


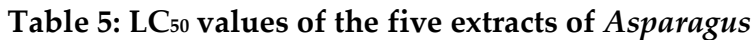
racemosus and standard.

\begin{tabular}{llll}
\hline Test Samples & Regression line & $\mathbf{R}^{2}$ & $\begin{array}{l}\text { LC }_{50} \\
\text { values }\end{array}$ \\
\hline Vincristine & $\mathrm{y}=29.79 \mathrm{x}+64.62$ & 0.927 & 0.323 \\
Methanol & $\mathrm{y}=20.13 \mathrm{x}+52.88$ & 0.959 & 0.719 \\
Ethanol & $\mathrm{y}=19.73 \mathrm{x}+53.38$ & 0.921 & 0.674 \\
Pet- ether & $\mathrm{y}=19.93 \mathrm{x}+50.13$ & 0.913 & 0.984 \\
n-hexane & $\mathrm{y}=25.16 \mathrm{x}+41.60$ & 0.945 & 2.157 \\
Chloroform & $\mathrm{y}=21.54 \mathrm{x}+46.12$ & 0.961 & 1.514 \\
\hline
\end{tabular}

$/ \mathrm{ml}$, where as ascorbic acid and BHT at the same concentration exhibited $96.66 \%$ and $92.59 \%$ inhibition respectively. Five extracts exhibited considerable DPPH free radical scavenging activity as indicated by their $\mathrm{IC}_{50}$ values and this has been showed in (Table 4 and Figure 1). IC 50 Indicate the potency of scavenging activity. Standard ascorbic acid and BHT were found to have an $\mathrm{IC}_{50}$ of 5.698 $\mu \mathrm{g} / \mathrm{ml}$ and $8.816 \mu \mathrm{g} / \mathrm{ml}$ respectively. In comparison to standard ascorbic acid and BHT, ethanol, methanol and petroleum ether extract of Asparagus racemosus root displayed $\mathrm{IC}_{50}$ of $78.15,106.44$ and 273.31 respectively. Chloroform and n-hexane fraction are seen to have the least free radical scavenging activity.

\section{Reducing Power Capacity Assessment}

Reducing power of the fractions was assessed using ferric to ferrous reducing activity as determined spectrophotometrically from the formation of Perl's prussian blue colour complex (Yildirim et al., 2001). Reducing power of different extracts of Asparagus racemosus was compared with ascorbic acid and BHT (Figure 2). Among the extract the chloroform extract exhibited the most reducing power.

\section{Cupric Reducing Antioxidant Capacity (CUPRAC)}

Reduction of $\mathrm{Cu}^{2+}$ ion to $\mathrm{Cu}^{+}$was found to rise with increasing concentrations of the different extracts. The standard ascorbic acid, BHA and BHT showed highest reducing capacity. Among the extracts the chloroform extract of Asparagus racemosus showed maximum reducing capacity that is comparable to ascorbic acid, BHA and BHT (Figure 3).

\section{Brine shrimp lethality bioassay}

In the present bioactivity study the five crude extracts and pure compounds showed positive results indicating that the test samples are biologi-

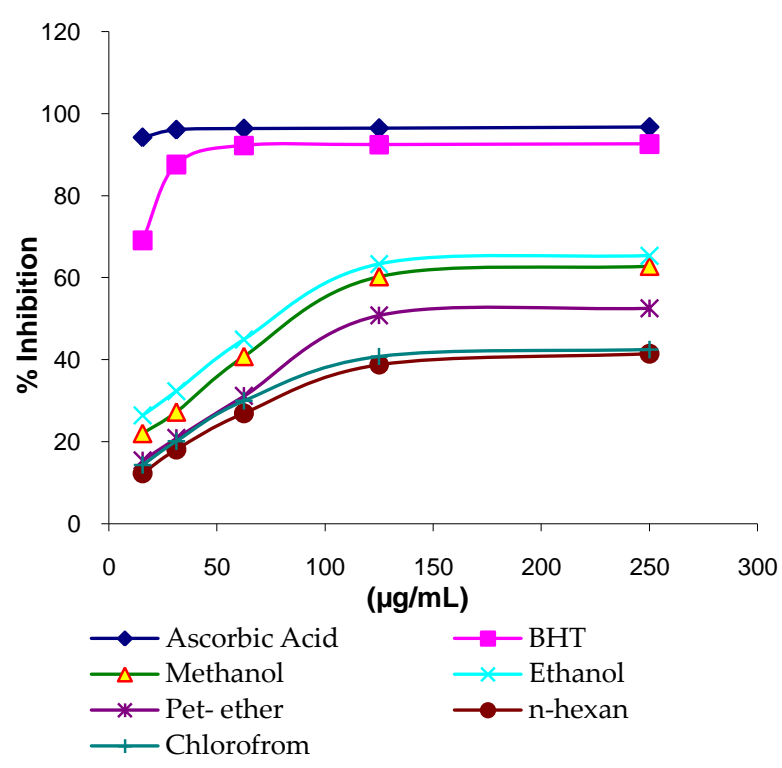

Figure 1: Comparative DPPH radical scavenging activity of Asparagus racemosus root extract, ascorbic acid and BHT.

cally active. The methanol, ethanol, petroleum ether, n-hexane and chloroform extract of the dried leaves of Asparagus racemosus were subjected to brine shrimp lethality bioassay following the procedure which has been utilized by Meyer et al., 1982. The lethality of the extractives to brine shrimps was determined and the results are shown in Table 5.

The lethal concentration ( $\left.\mathrm{LC}_{50}\right)$ of the test samples after 24 hours was obtained by a plot of percentage of the shrimps died against the logarithm of the sample concentration (toxicant concentration) and the best-fit line was obtained from the curve data by means of regression analysis. Vincristine Sulphate (VS) was used as positive control and the LC 50 was found as $0.323 \mu \mathrm{g} / \mathrm{ml}$. Compared with the negative control, VS gave significant mortality and the $\mathrm{LC}_{50}$ values of the different extractives were compared with negative control.

The $\mathrm{LC}_{50}$ values of ethanol, methanol, petroleum ether, n-hexane and chloroform were found to be $0.674 \mu \mathrm{g} / \mathrm{ml}, 0.719 \mu \mathrm{g} / \mathrm{ml}, 0.984 \mu \mathrm{g} / \mathrm{ml}, 2.157 \mu \mathrm{g} / \mathrm{ml}$ and 1.514 respectively (Table 5). However, varying degree of lethality of Artemia salina was observed with exposure to different dose levels top the test samples ranging from $0.781-400 \mu \mathrm{g} / \mathrm{ml}$. 


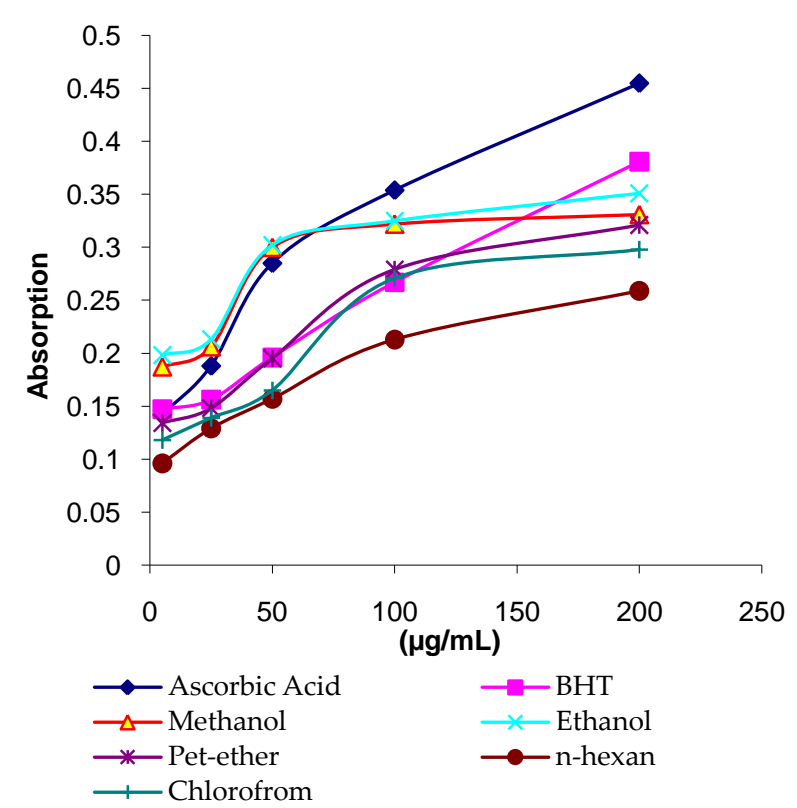

Figure 2: Comparative reducing power capacity of Asparagus racemosus root extract, ascorbic acid and BHT.

There was no mortality in the negative control groups indicating the test as a valid one and the results obtained are only due to the activity of the test agents.

\section{DISCUSSION}

In case of total phenol content determination, the results strongly suggest that phenolics are important components of the tested plant extracts. Literature revealed that antioxidant activity of plant extract is mainly due to presence of phenolic compounds, which may exert antioxidant effects as free radical scavengers, as hydrogen donating sources or as singlet oxygen quenchers and metal ion chelators.

Flavonoids play an important role in antioxidant system in plants. The antioxidative properties of flavonoids are due to several different mechanisms, such as scavenging of free radicals, chelation of metal ions, such as iron and copper and inhibition of enzymes responsible for free radical generation (Benavente-Garcia et al., 1997). Depending on their structure, flavonoids are able to scavenge practically all known ROS. According to our investigation, the high contents of flavonoids in Asparagus racemosus can explain its high radical scavenging activity.

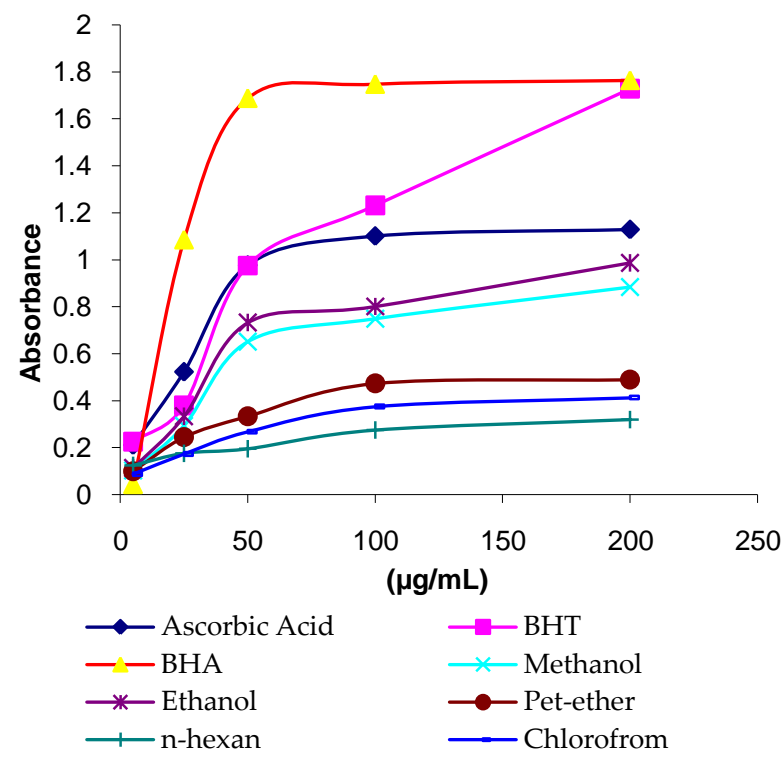

Figure 3: Comparative cupric reducing antioxidant Capacity of Asparagus racemosus root extract, ascorbic acid, BHT and BHA.

According to recent reports, a highly positive relationship between total phenols and antioxidant activity appears to be the trend in many plant species (Oktay et al., 2003).The statement has been justified in the current study where the ethanol extract of Asparagus racemosus showed maximum total antioxidant capacity (in term of ascorbic acid equivalent) (Table 3) with maximum phenol content (Table 1).

During comparative antioxidant study, all five extracts displayed considerable antioxidant activity in all three tests done for measuring this activity and this activity is justified by phenol, flavonoid content and total antioxidant activity. All the tests presented a positive relationship between each other what confirms the presence and extent of antioxidant activity. In DPPH scavenging activity, ethanol extract scavenged maximum than remaining four extracts which is may be due to its high phenol and flavonoid content. However, reducing power indicates that the extracts may consist of polyphenolic compounds that usually show great reducing power. This has been justified by ethanol extract being the most reducing agent with highest phenolic content (Table 1). Cupric reducing antioxidant capacity is based on the principle of increase in the absorbance of the reaction mixtures. Increase in the absorbance indicates increase in the antioxidant activity. Increase in 
absorbance of the reaction mixture indicates the reducing power of the samples (Jayaprakasha et al., 2001). Reducing power is associated with antioxidant activity and may serve as a significant reflection of the antioxidant activity (Oktay et al., 2003). Compounds with reducing power indicate that they are electron donors and can reduce the oxidized intermediates of lipid peroxidation processes, so that they can act as primary and secondary antioxidants (Yen and Chen, 1995).

In case of cytotoxicity, the degree of lethality shown by the extractives was found to be directly proportional to the concentration of the extractives ranging from the lowest concentration $(0.781 \mu \mathrm{g} / \mathrm{ml})$ to the highest concentration $(400 \mu \mathrm{g} / \mathrm{ml})$. This concentration dependent increment in percent mortality of brine shrimp nauplii produced by the Asparagus racemosus extracts indicates the presence of cytotoxic principles in these extractives.

\section{CONCLUSION}

All the conducted experiments in the present study are based on crude extract and are considered to be preliminary and more sophisticated research is necessary to reach a concrete conclusion about the findings of the present study. To sum up, these findings together demonstrate that Asparagus racemosus is an excellent plant candidate for further investigation of individual phenolic compounds, there in vivo antioxidant activity and the different antioxidant mechanisms and also appears to be a most promising candidate from which specific antioxidant bioactive products could be developed. Therefore, in depth extensive study should be an urgency to sort out bioactive compounds.

\section{REFERENCES}

Aderogba, M.A., Okoh, E.K. and Idowu T.O. (2005) Evaluation of antioxidant activity of the secondary metabolites from Poliostigma reticulatum (DC) hochst. Journal of Biological Sciences, Volume 5, Pages 239-242. [DOI]

Apak, R., Güçlü, K., Özyürek, M. and Karademir, S.E. (2004) Novel Total Antioxidant Capacity Index for Dietary Polyphenols and Vitamins C and E, Using Their Cupric Ion Reducing Capability in the Presence of Neocuproine: CUPRAC Method. Journal of Agricultural and Food Chemistry, Volume 52, Issue 26, Pages 7970-7981. [DOI] PMid: 15612784

Benavente-Garcia, O., Castillo, J., Marin, F.R., Ortuno, A. and Del-Rio, J,A. (1997) Uses and properties of Citrus flavonoids. Journal of Agricultural and Food Chemistry, Volume 45, Issue 12, Pages 4505-4515. [DOI]

Braca, A., Tommasi, N.D., Bari, L.D., Pizza, C., Politi, M. and Morelli, I. (2001) Antioxidant principles from Bauhinia tarapotensis. Journal of Natural Products, Volume 64, Issue 7, Pages 892-895. [DOI] PMid: 11473417

Da-Silva, J.F.M., De-Souza, M.C., Matta, S.R., De-Andrade, M.R. and Vidal, F.V.N. (2006) Correlation analysis between phenolic levels of brazilian propolis extracts and their antimicrobial and antioxidant activities. Food Chemistry, Volume 99, Pages 431-435. [DOI]

Demiray, S., Pintado, M.E. and Castro, P.M.L. (2009) "Evaluation of Phenolic Profiles and Antioxidant Activities of Turkish Medicinal Plants: Tilia Argentea, Crataegi Folium Leaves and Polygonum Bistorta Roots". World Academy of Science, Engineering and Technology, Volume 54, Pages 312-317.

Gautam, M., Saha, S., Bani, S., Kaul, A., Mishra, S., Patil, D., Satti, N.K., Suri, K.A., Gairola, S., Suresh, K., Jadhav. S., Qazi, G.N. and Patwardhan, B. (2009) Immunomodulatory activity of Asparagus racemosus on systemic Th1/Th2 immunity: implications for immune adjuvant potential. Journal of Ethnopharmacology, Volume 121, Issue 2, Pages 241-247. [DOI] PMid: 19038322

Jayaprakasha, G.K., Rao, L.J. and Sakariah, K.K. (2004) Antioxidant activities of flavidin in different in vitro model systems. Bioorganic \& Medicinal Chemistry, Volume 12, Issue 19, Pages 5141-5146. [DOI]

Kamat, J.P,, Boloor, K.K., Devasagayam, T.P. and Venkatachalam, S.R. (2000) Antioxidant properties of Asparagus racemosus against damage induced by gamma-radiation in rat liver mitochondria. Journal of Ethnopharmacology, Volume 71, Issue 3, Pages 425-435. [DOI]

Majhenic, L., Skerget, M. and Knez, Z. (2007) Antioxidant and antimicrobial activity of guarana seed extracts. Food Chemistry, Volume 104, Issue 3, Pages 1258-1268. [DOI]

Malorni, W., Rivabene, R., Lucia, B.M., Ferrara, R., Mazzone, A.M., Cauda, R. and Paganelli, R. (1998) The role of oxidative imbalance in progression to AIDS Effect of the thiol supplier $\mathrm{N}$-acetylcysteine. AIDS Research and Human 
Retroviruses, Volume 14, Issue 17, Pages 1589-1596. [DOI] PMid: 9840292

Mandal, S.C., Kumar, C.K.A., Mohana L.S., Sinha, S., Murugesan, T., Saha, B.P. and Pal, M. (2000) Antitussive effect of Asparagus racemosus root against sulfur dioxideinduced cough in mice. Fitoterapia, Volume 71, Issue 6, Pages 686-689. [DOI]

Meyer, B.N., Ferrigni, N.R., Putnam, J.E., Jacobsen, L.B. Nichols, D.E. and Melaughlin, J.L. (1982) Brine shrimp: A convenient general bioassay for active plant constituents. J. Planta Medica, Volume 45, Issue 5, Pages 31-34. [DOI] PMid: 17396775

Ojha, R., Sahu, A.N., Muruganandam, A.V., Singh, G.K. and Krishnamurthy, S. (2010) Asparagus racemosus enhances memory and protects against amnesia in rodent models. Brain \& Cognition, Volume 74, Issue 1, Pages 1-9. [DOI] PMid: 20594636

Oktay, M., Gulcin, I. and Kufrevioglu, O.I. (2003) Determination of in vitro antioxidant activity of fennel (Foeniculum vulgare) seed extracts. LWT - Food Science and Technology, Volume 36, Issue 2, Pages 263-271. [DOI]

Pandey, S.K., Sahay, A., Pandey, R.S. and Tripathi, Y.B. (2005) Effect of Asparagus racemosus rhizome (Shatavari) on mammary gland and genital organs of pregnant rat. Phytotherapy Research, Volume 19, Issue 8, Pages 721-724. [DOI] PMid: 16177978

Pauli, G.F., Case, R.J., Inui, T., Wang, Y., Cho, S., Fischer, H.H. and Franzblau, S.G. (2005) New perspectives on natural products in TB drug research. Life Sciences, Volume 78, Issue 5, Pages 485-494. [DOI] PMid: 16243360

Pereira, J.A., Oliveira, I., Sousa, A., Valentao, P. and Andrade, P.B. (2007) Walnut (Juglans regia L.) leaves: Phenolic compounds, antibacterial activity and antioxidant potential of different cultivars. Food and Chemical Toxicology, Volume 45, Pages 2287-2295. [DOI] PMid: 17637491

Potduang, B., Meeploy, M., Giwanon, R., Benmart, Y., Kaewduang, M. and Supatanakul, W. (2008) Biological activities of asparagus racemosus. African Journal of Traditional, Complementary and Alternative Medicines, Volume 5, Issue 3, Pages 230 - 237. PMCID: PMC2816549

Prieto, P., Pineda, M. and Aguilar, M. (1999) Spectrophotometric Quantitation of Antioxidant Capacity through the Formation of a Phosphomolybdenum Complex: Specific Application to the Determination of Vitamin E. Analytical Biochemistry, Volume 269, Issue 2, Pages 337-341. [DOI] PMid: 10222007
Rabaud, C., Tronel, H., Fremont, S., May, T., Canton, P. and Nicolas, J.P. (1997) Free radicals and HIV infection. Annales de Biologie Clinique, Volume 55, Pages 565-571. PMID: 9499916

Rege, N.N., Thatte, U.M. and Dahanukar, S.A. (1999) Adaptogenic properties of six rasayana herbs used in ayurvedic medicine. Phytotherapeutic Research, Volume 13, Issue 4, Pages 275-291. [DOI]

Rios, J.L. and Recio, M.C. (2005) Medicinal plants and antimicrobial activity. Journal of Ethnopharmacology, Volume 100, Issue 1\&2, Pages 80-84. [DOI] PMid: 15964727

Robert, A. and Meunier, B. (1998) Is Alkylation the Main Mechanism of Action of the Antimalarial Drug Artemisinin? Chemical Society Review Articles, Volume 27, Issue 4, Pages 273-274. [DOI]

Shah, P.M. (2005) The need for new therapeutic agents: What is in the pipeline? Clinical Microbiology and Infection, Volume 11, Issue 3, Pages 36-42. [DOI] PMid: 15900655

Visavadiya, N.P., Soni, B., Soni, B. and Madamwar, D. (2009) Suppression of reactive oxygen species and nitric oxide by Asparagus racemosus root extract using in vitro studies. Cellular and Molecular Biology, Volume 55, Pages 10831095. PMID: 19267991

Wang, S.Y. and Jiao, H. (2000) Correlation of antioxidant capacities to oxygen radical scavenging enzyme activities in blackberry. Journal of Agricultural and Food Chemistry, Volume 48, Issue 11, Pages 5672-5676. PMid: 11087537

Wiboonpun, N., Phuwapraisirisan, P. and Tip-pyang, S. (2004) Identification of antioxidant compound from Asparagus racemosus. Phytotherapy Research, Volume 18, Issue 9, Pages 771-773. [DOI] PMid: 15478181

Yen, G.C. and Chen, H.Y. (1995) Antioxidant Activity of Various Tea Extracts in Relation to Their Antimutagenicity. Journal of Agricultural and Food Chemistry, Volume 43, Issue 1, Pages 27-32. [DOI]

Yildirim, A., Mavi, A. and Kara, A.A. (2001) Determination of Antioxidant and Antimicrobial Activities of Rumex crispus L. Extracts. Journal of Agricultural and Food Chemistry, Volume 49, Issue 8, Pages 4083-4089. [DOI] 